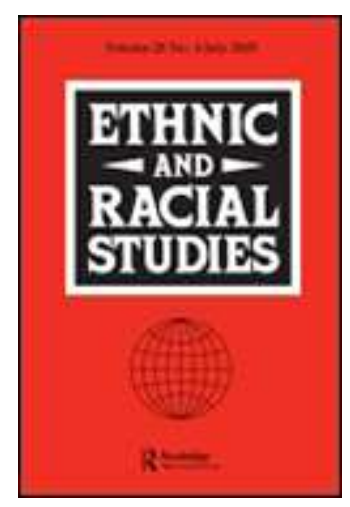

\title{
Codevelopment and citizenship: The nexus between policies on local migrant incorporation and migrant transnational practices in Spain
}

\begin{tabular}{|r|l|}
\hline Journal: & Ethnic and Racial Studies \\
\hline Manuscript ID: & RERS-2008-0296.R3 \\
\hline Manuscript Type: & Original Manuscript \\
\hline Keywords: & $\begin{array}{l}\text { Citizenship, Transnational migration, Local government, Spain, } \\
\text { Codevelopment, Catalonia }\end{array}$ \\
\hline
\end{tabular}

\section{S ScholarONE \\ Manuscript Central}




\begin{abstract}
Over the last decade both national and local actors in Spain have picked up on international trends encouraging a policy framework of migration and development. Policies of codevelopment are tied in with issues of migration management in the sense of linking current and future migration flows with processes of development in the country of origin. However, this article demonstrates how codevelopment policies and initiatives of local governments in Catalonia also relate to migrants' local process of incorporation in their country of residence. In so doing the article seeks to bridge and contribute to studies of migration and development as well as issues of national and local citizenship and migrant incorporation. Importantly, the article highlights the role of receiving country local governments in the nexus between migrant transnational practices and processes of incorporation.
\end{abstract}

Keywords: Spain, Catalonia, codevelopment, citizenship, transnational, migration 


\section{Introduction}

Citizenship occupies a central place in debates and policies on migrant incorporation in contemporary Europe (Bauböck et al. 2006; Faist 2007). It highlights the tension between the mobility of persons, the interconnectedness of societies and the boundedness of states. Migrant cross border attachment and engagement challenge a state-bound definition of citizenship understood both as a legal status with political rights and as various forms of political participation (Blomraad et al. 2008). This is reflected in the policies of external citizenship and the long-distance governing of expatriates implemented in an increasing number of emigration countries (Levitt and Dehesa 2003; Østergaard-Nielsen 2003a). But which new forms of citizenship policies which try to incorporate the transnational dimension of migrant civic and political engagement are emerging in receiving countries?

The emerging policy field of codevelopment in Spain provides an interesting case of the nexus between especially local citizenship and migrant transnational practices. The linking of migration and development has gained remarkable currency in Mediterranean countries. Regional, national and local political actors have picked up on international trends encouraging a multi-level public policy that promotes the role of migration and migrants in development of their countries of origin. As will be detailed below, Spanish codevelopment policies were initially primarily related to how migration management (return migration) and remittances could improve conditions in the migrant sending context. However, one of the key aims of this article is to highlight how policies of codevelopment in Spain increasingly also link up with policies of citizenship and migrant incorporation. Under the heading of codevelopment, especially local governments include migrant transnational interest in the development of their country of origin as part of their strategies for local migrant incorporation. It is therefore 
relevant, even at this relatively experimental stage, to take stock of what type of citizenship for migrants which is being envisioned in the current policy environment of codevelopment and how this combines with policies on migrant incorporation.

The Spanish and Catalan case cuts across three important themes of migration in Europe and North America. On the one hand there is the formulation of national and local regimes of citizenship and migrant incorporation strategies. On the other hand there is the growing attention to migration and development and the role of migrants as actors in development. In between these two themes is the third theme of the scope and impact of the transnational practices of migrants and diasporas and the dialectic of stateled vs. migrant-led transnationalism. This analysis of the nexus between codevelopment and citizenship ties together and contributes to these three themes along the following lines:

First, a large part of the literature on migrant membership in a transnational optic focuses on the policies of the countries of origin in extending various forms of citizenship or membership to their emigrants residing elsewhere (Østergaard-Nielsen 2003a; Smith 2007). This analysis, however, centres on the role of the country of residence. It shows how especially local governments have embarked on supporting transnational activities of migrants not just in order to change things in their country of origin, but as a part of migrant local membership, that is, their relationship with local and national authorities in their country of residence. Second, comparative studies of the relationship between citizenship in the countries of residence and migrant transnational engagement have tended to analyse the latter as a dependent variable of the former (Østergaard-Nielsen 2001; Koopmans and Statham 2003). Alternatively, scholarship have tuned in on the compatibility between migrant transnational orientation and practices and processes of integration, underscoring the dilemmas of dual loyalties or 
national identities (Østergaard-Nielsen 2001; Smith 2007, Martinello and Lafleur 2008). In contrast, this article presents a case where there is a policy environment directly encouraging migrant transnationalism. The extent to which such policies link up with citizenship either explicitly or by default makes for an interesting contribution to the European landscape of perceptions and politics of migrant transnationalism.

Third, this analysis highlights the role of regional and local government as central to the political environment of linking migrants' local and transnational engagement. Local governments in the receiving countries have come to the fore in studies of migrant integration policies. However, in terms of migrant transnational practices, European based scholarship has tended to favour a national paradigm over a local one (Bauböck 2003b; Østergaard-Nielsen 2003b; Caglar 2005). In this article I aim to demonstrate how an analysis of the local level paints a more complex and nuanced picture of the relationship between citizenship and migrant transnational practices. Indeed, codevelopment policies in the optic of migrant incorporation embody a concomitant localization and transnationalization of migrant citizenship.

In the following pages, I first set the context for the analysis by locating the case-study in the wider scholarship on the relationship between national and local policies on citizenship, local and regional governance structures and migrant transnationalism. This is followed by an analysis of policy documents on both citizenship and codevelopment in Spain and Catalonia highlighting the growing importance of the local and the transnational. I then analyse two interrelated dimensions of codevelopment practices among Catalan municipalities and other local actors: the codevelopment projects and the attempts to mobilize migrants for further participation in projects. 
The analysis presented here stops short of evaluating the eventual outcome of migrant engagement in codevelopment, but focuses on how the nexus between local migrant incorporation and transnational practices is reflected in policy plans and activities of local governments and migrants at the national, regional and local level. In so doing this article draws on the Catalan component of a multi-sited data collection on co-development and migrant transnationalism in Spain. ${ }^{1}$ This research includes analysis of policy documents and other types of written material, and 54 in-depth interviews with representatives of regional and local governments, Moroccan and Latin American migrant associations and various types of NGOs working within the field of codevelopment and migration. ${ }^{2}$ Moreover, an important part of the study is the participatory observation in meetings and seminars on codevelopment in Catalonia or elsewhere in Spain.

\section{The nexus between citizenship and migrant transnational practices: new prospects and old limitations}

All EU-15 member states have revised their citizenship laws in the face of immigration over the last decades (Bauböck et al. 2006) and a growing field of literature has analysed both trends of restriction and liberalization of migrant access to citizenship (Bauböck et al. 2006; Faist 2007; Joppke 2008). A key part of the liberalising trend is the growing tolerance of dual citizenship, which acknowledges that migrants may retain an attachment to their country of origin and that national loyalty is not necessarily exclusive (Faist 2007). This tolerance is not, however, synonymous with acceptance of migrant transnationalism. A central argument in support of dual citizenship in European immigrant receiving states is that it encourages naturalization among both immigrants and emigrants otherwise reluctant to let go of their original nationality. That is, policies 
of citizenship in migrant receiving countries, including dual citizenship, are focused on strengthening the relationship between migrants and political institutions in their country of residence. Meanwhile, state responses to immigrant transnational political engagement mainly veer between indifference, tolerance or securitization, but rarely direct encouragement (Østergaard-Nielsen 2008).

National citizenship is the main gateway for immigrants to EU, national and local political rights. However, over the last decades scholars have argued that the idea of citizenship as related to the nation-state only, is challenged by concomitant and interrelated processes of globalization and localization. While the concept of postnational citizenship originally sought to capture the growing legitimation of personal rights in global human rights regimes (Soysal 1994), more recent work emphasizes how the local, especially the urban local, is a key site for the enactment of post-national citizenship (Sassen 2002; Benhabib 2007). Indeed, the local has come to the fore in studies of migrant incorporation as a range of scholars have pointed to the significance of different subnational configurations of citizenship and migrant incorporation (Favell 2001; Ireland 2004; Penninx and Martinello 2006). These differences, it has been argued, respond to the fact that local transformations brought about by concomitant processes of globalization and migration are uneven within and across national territories (Glick-Schiller and Caglar 2008). Thus, including dynamics at the level of local governments (and cities) provide a more complex picture of migrant incorporation in both a local and transnational scenario.

The growing role of local, often urban, governments for migrant incorporation is located in processes of decentralization of public policy and a strengthening of local membership and democracy derived from policy developments at both the EU- and the national level. Political electoral rights are more widely extended at the local level, as 
EU citizens can vote in local elections throughout the EU and a significant number of EU-member states have also granted local voting rights to third country citizens (Groenendijk 2008). In terms of other types of political engagement, subnational levels of governments have been found to formulate and practice policies of membership for newcomers, which may differ from the experience at the national level. The local dimensions of citizenship imply the incorporation of stakeholders in local decision making, policy formulation and implementation through processes of governance. Local processes of governance are also extended to migrants although the actual processes of inclusion are sometimes tempered by the relative lack of resources among migrants (Pero 2005; García 2006). As pointed out by García (2006), despite the emphasis on the inclusiveness of the citizenship implied in local or urban forms of governance, the political rights are territorially embedded at the European or national level (García 2006). Those third country migrants who reside in member states that do not grant them local voting rights are therefore more dependent on the practice of local governance than those for whom it is an extra and complementary opportunity for political influence.

Given the role of regional and local government for migrant incorporation and the growing significance of local forms of membership, it is also relevant to investigate how this local policy environment relates to migrant transnational practices. As mentioned, the scholarship on urban citizenship sees the local as increasingly global, emphasizing how the plurality and connectedness of cities render them sites of cosmopolitanism (Sassen 2002; Benhabib 2007). Extended to the issue of migrant transnationalism, an obvious hypothesis is that local citizenship is not exclusive to the same extent as national citizenship, because it is not a full contract between citizens and the state. For instance, Bauböck (2003) argues that local or city governments are likely 
to be more open to migrant transnational affiliations than are national ones (Bauböck 2003b; Bauböck 2003a).

The bulk of empirical studies on how local governments might perceive and act upon migrant transnationalism, however, centres on the local governments in the countries of emigration. ${ }^{3}$ For instance, local and regional governments in Mexico have actively encouraged migrants to contribute to the development of their hometowns, thus institutionalizing forms of transnational citizenship in the country of origin (Goldring 2002; Smith 2006). ${ }^{4}$ In her analysis of this phenomena, Goldring (2002) concludes that state-migrant relations in a transnational optic are best understood as a 'set of negotiations over meanings and privileges attached to "membership" in the national or sub-national community (...)' (Goldring 2002, p. 93). By contrast, as the following case-study will show, the receiving state-migrant relations in the context of codevelopment are not transnational in and of themselves. Instead it is a set of negotiations about the meaning of the transnational dimension of local membership between a state and its subjects within the same territory.

\section{National and local citizenship in Spain}

During the last decades Spain has been one of the main net receivers of international migration in Europe. While half a million migrants were legally residing in Spain in 1991, the number of both regular and irregular migrants in 2008 was more than 5,22 million according to the figures of municipal registration [padrón municipal] (INE 2008).

Policies of citizenship and migrant incorporation in Spain have long taken the backseat to policies on control of especially irregular flows of immigration. Access to citizenship as a formal legal status, has not been modified to a very great extent. Indeed, 
despite the last decades of intense immigration, Spanish citizenship policies still bear the hallmark of Spain's experience as an emigration country. One example is the modification of the law on citizenship in 2002, whereby the Spanish government facilitated the option for Spanish emigrants to retain their Spanish nationality when naturalizing abroad while formally denying the same right to immigrants (Marín 2006). Spanish citizenship laws are also influenced by the country's colonial past. Latin American migrants are fast-tracked to naturalize after only two years while other immigrant collectives have to wait for ten years (ibid).

There has been more happening in terms of defining a local citizenship for newcomers in the context of national and regional plans for migrant incorporation and participation. Migrant incorporation in the face of the rapidly growing local diversity poses a challenge for local and national policy makers in Spain. With the Strategic Plan for Citizenship and Integration, 2007-10, the Spanish government launched its first more comprehensive plan for migrant incorporation with a budget of just over 200 million Euros (Ministerio de Trabajo y Inmigración 2007). ${ }^{5}$ This development was inseparable from the dynamics at the level of the autonomous communities. The policy plan was in part the result of pressure from regional and local governments some of which have been formulating their own policy plans for migrant incorporation since the 1990s. Moreover, the budget of the Plan was largely to be redistributed among regional governments. Indeed, policies of citizenship and migrant incorporation in Spain are characterized by regional and national differences (Bruquetas-Callejo et al. 2008).

In the case of Catalonia, policies of citizenship are embedded in the ongoing nationalist project of consolidating Catalan identity and autonomy within the Spanish political framework and in the face of past internal and current international migration (Castiñeira 2007; Zapata-Barrero forthcoming). The most recent examples are the 
prioritizations in the Catalan Plan of Citizenship and Immigration, 2005-8 (Generalitat de Catalunya 2006), which was followed by a National Agreement on Immigration (Generalitat de Catalunya 2008). These policy documents emphasize the importance of newcomers learning the Catalan language. At the same time, they employ an inclusive and ambitious language of promoting equality, pluralism and an inclusive citizenship extended to all newcomers.

In the Spanish Plan, migrant citizenship is envisioned as the citizenship of the city [ciudadanía de la ciudad], and the term interculturalism [interculturalidad] appears as one of the main pillars in the Plan although it remains vaguely defined. In the Catalan Plan the term citizenship of residence [ciudadanía de residencia], defines all residents of Catalonia as Catalan citizens and emphasizes the principles of pluralism and equality. In this context the two most relevant characteristics of the model of citizenship in both Spanish and Catalan policies are: first, the promotion of a civic citizenship where migrants are encouraged to participate actively in political and social affairs. Second, that this active incorporation takes place in the local context. This promotion of a localized civic membership falls short of being accompanied by local voting rights because of restrictions posed by the current constitution (Ministerio de Trabajo y Inmigración 2007). ${ }^{6}$

\section{The many and multi-level meanings of codevelopment in Spain}

Why codevelopment has emerged as a policy-field bridging the issues of migration and development in Spain is a research question in and of itself. Among the explanations is the abovementioned intense inflow of migrants. Codevelopment policies have mainly been linked to issues of migration management and its advocates envision the more 
long-term focus on the root causes of migration to constitute a counterweight to the focus on security and control.

Moreover, Spanish documents and speeches on codevelopment take their clue from the international recent round of interest in migration and development (Lacomba 2004; Gil 2005). From the international level the most important reference points are the UN summit in 1997, the Global Commission on International Migration, and the European Union. ${ }^{7}$ Another important point of reference for the Spanish notion of codevelopment is France. In particular the work of the French academic and policy advisor Sami Naï, which emphasized the role of migrants as actors in development, has been widely cited in the Spanish context. ${ }^{8}$ France apart, more comprehensive policies on codevelopment in other EU-member-states are few and far in between. Initiatives to link migration and development are certainly not new. This also formed part of the logic of remittance investment and migrant return schemes during and after the 'guestworker' recruitment period up till 1973. More recent initiatives to include migrants in development projects in their countries of origin have been identified among both government and non-government actors in the United Kingdom, the Netherlands, Belgium and Italy (de Haas 2006).

It is early days in terms of a real set of Spanish and Catalan policies on codevelopment. Consequently, the term co-development is still somewhat ambiguous and continues to be defined in a variety of ways with different actors and documents emphasizing different aspects and priorities. One general trend, however, is the gradual shift from the focus on the link between development and migration management to the link between development and migrant integration. The first state level policy plan including codevelopment was The Global Programme to Regulate and Coordinate Foreign Residents' Affairs and Immigration (Programa Greco) (Ministerio del Interior, 
2000). The definition of co-development in the Programa Greco favoured promoting and facilitating the return of migrants above encouraging a transnational migrant civic engagement among migrants residing in Spain. Indeed, the sections on codevelopment are more concerned with the re-integration of migrants in their countries of origin than their process of settlement in Spain. The emphasis on migration management is also present in both the Spanish Master Plan for Cooperation, 2005-2008 (Ministerio de Asuntos Exteriores y Cooperación, 2005), and the aforementioned Spanish Strategic Plan for Citizenship and Integration. Yet, these two policy plans also focus on the importance of implicating migrants as actors of development through their transnational resources. In the Strategic Plan for Citizenship and Integration it is stated that a good integration of migrants is the first step for a process of codevelopment to develop and more than 55 million Euros are dedicated to codevelopment initiatives in collaboration with the Foreign Ministry and the Spanish Development Agency (AECID).

Development cooperation is not a state prerogative in Spain and several autonomous communities have begun defining their own codevelopment policies including Andalucía, Catalonia and the Basque Country (Gil 2005). ${ }^{9}$ In the case of Catalonia, the link between migrant transnational engagement in the development of their countries of origin and the issue of migrant incorporation has been explicitly mentioned in policy documents for a longer time than is the case at the level of the Spanish State. According to the Interdepartmental Plan for Immigration, 2001--4, Catalonia may influence the development of immigrants' countries of origin by awareness raising and training in development cooperation with the aim of encouraging a joint sense of responsibility and closer relations with immigrants' societies of origin (Generalitat de Catalunya 2001). Similarly, in the more recent Catalan Master Plan for Development Cooperation 2003-2006, which came almost two years before the 
Spanish ditto, co-development features as one of the four main strategic objectives and the issue of co-development is anchored also in the overall understanding of migrant incorporation. The document states that '[...] the aim of co-development must be to favour social integration of migrants in host communities, aiding them to maintain their transnational ties with their countries of origin.' (Generalitat de Catalunya 2003). ${ }^{10}$

Critical voices from especially the development cooperation sector have questioned the developmental impact of codevelopment projects, and have warned against spending money designated for development abroad on processes of migrant incorporation at home (Royo 2008). Still, the growing emphasis on the link between migrant incorporation and development has been largely well received. It acknowledges that migrants can be actors in development in their countries of origin, not just by returning but from afar. This leads to two suppositions about the relationship between integration and codevelopment: On the one hand that the inclusion of migrants in decentralized development collaboration in their country of origin may foment their integration, especially understood as the political incorporation of migrant associations. On the other hand that 'good' integration is conducive to migrant transnational engagement in codevelopment. This implies that codevelopment signifies the acceptance of a transnational dimension of citizenship for migrants, although within the parameters of the civic and economic rather than the overtly political and controversial.

\section{The relevance of local governments in codevelopment practices in Catalonia}

In the case of Catalonia, the debate on the division of labour between different levels of government within codevelopment is still ongoing. Meanwhile a series of local governments have been engaged in codevelopment and in connecting migrant transnational agency with local processes of incorporation. There are several structural 
explanations for the engagement of local governments in codevelopment. First, in terms of migrant incorporation, local governments in Catalonia, as is the case in other parts of Spain, are concerned with formulating a more comprehensive framework for incorporation of migrants, sometimes pioneering strategies not yet considered at the regional or national level (Pajares 2006). As outlined in the current Catalan policy programme on migrant incorporation, it is desirable to promote an increasingly institutionalized dialogue between local government and migrant associations on the issues of concern to both. This has resulted in an effort to identify and collaborate with interlocutors from the main migrant collectives.

Second, local governments in Catalonia, as elsewhere in Spain, have experience within the field of so-called decentralized development cooperation (Gil 2008; Dalmases 2009). Of the 940 municipalities in Catalonia, 400 municipalities (representing 90,2 per cent of the Catalan population) are known to have undertaken projects of development or emergency relief (Fons Catalá 2007a). ${ }^{11}$ The amount of money involved is not dramatic. Collectively local governments in Catalonia spent approximately 21 million Euros on development activities in 2005. Still, municipalities may have their own annual plans for international cooperation on development and a budget that strives towards reaching 0.7 per cent (as is the aim on the state level). Traditionally, this international development cooperation has mainly been in the form of 'twin citiying' with a town or municipality outside of Europe. However, a growing number of municipalities have personnel dedicated to international decentralized development projects in collaboration with local, regional or national development agencies and NGOs. Municipalities have councils for development cooperation [Consells Solidaris], which usually include representatives from the municipality, local NGOs and local branches of national or international NGOs. 
Finally, an important catalyst for the increased synergy between migration and development related issues at the local level is the development cooperation agency of the municipalities in Catalonia called Fons Català de Cooperació al Desenvolupament. The Fons Català serves to coordinate the development activities of the municipalities and provide technical assessment and expertise. Fons Català has worked with codevelopment since 1996 and thus been among the pioneers within this field in Spain. The codevelopment work of the Fons Català stands out for its focus on the active implication of migrant associations in projects of development in their country of origin. In the definition of the Fons Català codevelopment is linked up with 'municipalism' [municipalismo], a governance style concept denoting the strengthening of capacity, democracy and participation of local government (Fons Catalá 2007b). Thus codevelopment is promoted as a new instrument for not just doing development work, but also for working with local governments on 'issues of citizen participation and integration of migrants in their societies of settlement, that is to work for their implication in local politics' (Ibid).

\section{Codevelopment in practice: 'integration here, development there'}

The nexus between codevelopment and local migrant incorporation in policy documents and plans is reflected in the growing number of codevelopment projects. Codevelopment is still a minor area of local decentralized development cooperation with the Fons Català having spent just under four million Euros on approximately 91 projects. To this must be added projects financed by other levels of government and the EU. As already indicated the involvement of municipalities in codevelopment is highly uneven. The vast majority are not active at all, while some finance a range of projects coordinated by a defined codevelopment policy updated in yearly plans. Some of the 
bigger metropolitan municipalities such as Barcelona and in particular Lleida, which have more resources at their hand, are not surprisingly also those with more projects. However, even quite small municipalities have ventured into the field of codevelopment in collaboration with migrants (Fons Catalá 2007b). The question of why some municipalities are more active in codevelopment than others warrants more systematic information and analysis. In the interpretation of Fons Catala the decisive factors explaining why some municipalities at this point in time have become involved in codevelopment are the amount of experience with decentralized development cooperation, the political colour of the local government and the presence of sizeable migrant collectives (Interview, Fons Catala, Barcelona 2009).

The nexus between migrant transnational resources and local incorporation is manifest in two key dimensions of the municipal implementation of codevelopment. First, the extent to which issues of local migrant incorporation figure in the justification and design of the codevelopment projects themselves. Second the processes of mobilization aimed at those migrant collectives who are not yet participating in codevelopment to a very great extent.

The incentive of local governments to engage in codevelopment follows the general idea outlined above of killing two birds with one stone: to consolidate the collaboration between migrants and local Catalan actors through decentralized development corporation in their countries of origin. Thus, for local governments codevelopment meets local demands for more development collaboration and spending money on local co-existence (Interview with Fons Catala, Barcelona, 2009). The notion of a potential contradiction between local incorporation and transnational ties of migrants is not seen as relevant. On the contrary, as expressed by a councillor from the small town Perpetua de Montgoda: 
We believe [...] that we have to abandon the idea that those who want to integrate need to cut their ties to their communities of origin $[\ldots]$ if we are able to work together and reach important objectives [of codevelopment] how can we not be able to live together in mutual respect and with common objectives, both here and there? (Speech, Perpetua de Montgoda 2006)

Regarding the projects, these can take a variety of forms and relate to different themes. Among the mainly small-scale projects investigated in greater detail are migrants' efforts to better infra-structure in the village of origin, improve health care facilities, generate employment through for instance cooperatives, and contribute to the education of children, women or unemployed youth. These projects are realized with Catalan (or Spanish) public funding and so far no 'official' codevelopment project has been encountered where the migrants also contribute financially, as in the case of the 3 for 1 programmes in Mexico (Goldring 2002). Sometimes there is a contribution from the local authorities in the country of origin, often paid in kind by providing part of the local resources (terrain, construction material, local experts). For instance, in Sant Feliu, a small town on the outskirts of the Barcelona region, an Ecuadorian association is collaborating with the municipality on a project involving the construction of a kindergarten in their home village in order to support mothers working outside the home. The municipality in the town of origin is to provide the land, while the Catalan local government finances the rest of the project (interview, Sant Feliu de Llobregat 2006 and 2007).

In projects of codevelopment, the synergy with processes of local migrant incorporation is not just a by-product of the fact that migrant associations collaborate with the local administration in Catalonia. In some projects the issues of migrant 
incorporation figure as one of the project goals, in the sense of the project including capacity building among migrant associations. Another line of activity is to support processes of migrant integration through the promotion of a greater understanding of the particular social, cultural, ethnic and political conditions in their localities of origin [promoción intercultural]. Moreover, projects envisage migrant led development projects as a stepping stone to intensifying transnational relations with the locality where the project is implemented. A recent project initiated by a Barcelona based Moroccan association and the local government of Terrassa has the dual aim of reducing maternal mortality rates in Bni Idder in Northern Morocco, and strengthening ties and exchanges between the civil society actors and administration in the Catalan and Moroccan localities involved (Fons Catalá 2008).

The nexus between migrant transnationalism and local incorporation is also very explicit in the processes of mobilization of migrants for codevelopment. It is important not to take for granted that migrants want to participate in codevelopment projects. Indeed, the participation of migrants in codevelopment in Catalonia is generally very mixed and certainly not representative of the size or multitude of nationalities living there. The migrant collectives with by far the highest participation rate are from subSaharan Africa. For instance, of the 91 projects on codevelopment funded by the Fons Català countries like Senegal (30 projects), Guinea Ecuatorial (17 projects) and Gambia (12 projects) account for approximately 60 per cent of the projects although these migrant collectives account for approximately 3 per cent of the migrant population in Catalonia. ${ }^{12}$ The greater involvement of these migrants groups needs to be understood in the context of a number of other factors including the timing, nature and efficiency of their local and transnational networks (Sow 2005) and the special attention their countries of origin have received by central actors in the sector of development 
cooperation in Catalonia. By contrast, the two largest migrant groups in Catalonia, Moroccans and especially Ecuadorians are much less involved. In interviews with Moroccan and Latin American migrant associations who are not yet involved in codevelopment, representatives emphasize that they are prioritizing activities directly related to their process of settlement such as residence permits, family reunification, discrimination on the labour market, the education of second generation migrant children, etc. (Østergaard-Nielsen 2009).

With regard to the policy environment on co-development, associational representatives do, not surprisingly, reveal a number of differing opinions. On the one hand migrant representatives are generally very positive about the idea of involving them in projects of development in their localities of origin. On the other hand some migrant representatives are highly sceptical about the way that codevelopment is being implemented. They feel that they are token participants without any real influence. The development community is criticized for plotting migrants into an already fixed development agenda when and how it suits them, without giving migrants any influence on the political process which establishes the parameters for this type of collaboration in the first place.

In order to include more migrant collectives in projects of codevelopment the Fons Catala and a number of NGOs have undertaken a range of activities. Indeed, a not insignificant amount of funding and projects, which local governments or various Catalan development agencies or development NGOs categorize as codevelopment, take place on Catalan territory exclusively. Generally, sensitizing the Catalan population around development issues is seen as an integral part of the wider political strategy for international aid and development cooperation. In the case of codevelopment, an analysis of projects in 2004 reveal that approximately 20 per cent of codevelopment 
funds are spent on awareness raising activities and capacity building in Catalonia (Fons Catalá 2007a). One aspect of this is the organization of conferences and seminars in order gather experiences and lessons from local and international actors. For instance, Fons Català or the farmers trade union Pagesos Solidaris have organized seminars on codevelopment where the concept and its implications are debated among the most important stakeholders such as municipalities, development NGOs and migrant associations. Such seminars also serve to explain the parameters and funding possibilities for codevelopment to migrant associations, and usually migrant associations already engaged in codevelopment are invited to present their project and experiences.

Illustratively, a seminar organized in the municipality of Montcada i Reixac, with representatives of the local government and administration, Moroccan and Ecuadorian migrants and the Fons Català, had the title: 'Integration here, development there: challenges for codevelopment'. At this venue the head of the Fons Català argued that integration is an important premise for codevelopment and that codevelopment activities may help bolster the visibility of migrants in their local environment:

It is important that we have interlocutors, and to that end it is important that the migrants are organized and that their associations are incorporated in a more clear way in the social fabric of the cities, that they do not become invisible (Speech, Montcada i Reixac 2007).

In a more recent development a series of municipalities have organized courses in decentralized development cooperation for migrants. These courses were often financed and designed in collaboration with Fons Català and aim to train migrants in development work by explaining the migration-development nexus and the possibilities 
of codevelopment. The course design reviewed for this research include sessions explaining the basic principles of development collaborations as defined by the Catalan actors: how to formulate and manage a development project (the project cycle) and also convey what is thought to be the most important transversal themes such as gender and environment.

Another type of activity is to commission studies of the type of activities that have already taken place in Spain or Catalonia in order to draw lessons from the growing number of local experiences or assess the potential for codevelopment projects among particular migrant collectives. For instance, one publication explores lessons from the Senegalese migrant collectives' relative extensive experience (Sow, 2005). Importantly, there have been fact-finding studies of migrant collectives and associations in order to assess and reinforce their capacity to be development actors. In the case of the Moroccan migrants, the Fons Català contracted a Moroccan origin expert on codevelopment who during his employment undertook an impressive round of consultations with the Moroccan migrant associations all over Catalonia (ØstergaardNielsen 2009).

The theme of integration and political incorporation of migrants cuts across these activities. As stated in the preamble to one of the codevelopment projects of the municipality Mataró on the outskirt of Barcelona, 'codevelopment is consolidating itself as a model of collaboration with migrants'. ${ }^{13}$ The process of mobilization of migrants around codevelopment in Catalonia (and elsewhere in Spain) is a process of integration in and of itself. Not only because events on codevelopment invariably touch on issues of integration and rights for migrants in Catalonia, but also because the very dialogue on how migrants can be agents for development in their country of origin is a dialogue on what type of membership that Spain/Catalonia envisages for its migrants. 


\section{Conclusions}

Both citizenship and codevelopment are emerging policy fields in Spain and Catalonia. This limits the available empirical material and hence the scope of the conclusions. In particular, it is early days to evaluate the crucial dimension of the actual impact of the migrant led development projects on local processes of change in their countries of origin. Still, in terms of the dynamics in the country of residence, the policy framework and growing number of codevelopment activities provide an interesting venue for probing into the nexus of local and transnational relations between migrants and states.

Codevelopment and citizenship are intrinsically linked both at the level of policies and practices among local governments and the migrants themselves. The kind of citizenship implied in codevelopment policies and initiatives has three main components: it is local, it is participatory and it is transnational. It is local because it is tied in with the policies of mainly local governments and enacted at the local level. It is participatory, and mostly on a collective level, because it encourages the capacity building of migrant associations and representatives and their active participation in local affairs and networking with other local actors. Finally, the citizenship encouraged within codevelopment practices is transnational because migrant transnational interests, contacts and engagement are seen as an integral part of their local incorporation. The local and participatory role for migrants in codevelopment policies echoes the emerging Spanish and Catalan migrant incorporation policies of 'citizenship in the city' and 'citizenship of residence', and wider notions of civic and post-national citizenship practiced at the local level. The transnational element positions the citizenship of codevelopment as an example which adds to the growing evidence of the unboundedness of the local, but reflected in public policy of the receiving states. In this 
way the citizenship implied in codevelopment activities signifies a new type of local membership where transnational and local migrant engagement is not perceived as incompatible. Even in the context of Catalonia where current policies of migrant incorporation are tied in with the nationalist project of consolidating Catalan language and identity, migrant incorporation is also located in wider processes of local solidarity engagement of Catalan actors.

Clearly it is important not to conflate the national with the local level. Although also the state-level programmes on codevelopment in Spain link up with notions of migrant incorporation, the Catalan case shows how it is mainly at the local level that such policies are enacted. This provides an example of how sub-national governments, in practice, can be more open to migrant transnational ties and practices. These local sites are embedded in the multi-level policy environment on development and citizenship. And further comparative research is needed in order to better understand why certain local governments or societies, as in the case of Catalonia, are more ready to promote migrant transnational ties and engagement in codevelopment than others.

Citizens increasingly live their lives across borders. The task of facilitating their multiple political incorporation, in particular in their countries of residence, poses an important challenge for policy makers. The codevelopment idea of 'integration here, development there' covers new ground compared to both local and national debates on neo assimilatory or civic models of migrant incorporation in other EU-member states with a longer immigration trajectory. Through codevelopment policies and practices a transnational dimension is added to the European project of institutionalizing a multilayered participatory citizenship. The encouragement of a horizontal cross-border local civic participation of migrants does, however, fall well short of securing vertical lines of political influence for migrants. Among the premises for this local inclusiveness of both 
the local and transnational engagement of migrants is that there is less at stake. Despite the discourse of promoting equality, the 'citizenship of the city' or the 'citizenship of residence' is not a full contract between the state and newcomers securing the equal opportunity for political influence of newcomers and natives. And only when more codevelopment projects run their course will it be possible to evaluate to what extent the citizenship of codevelopment creates a positive dynamic between migrants transnational engagement in codevelopment and their local political incorporation. 


\section{References}

BAUBÖCK, RAINER 2003a 'Reinventing urban citizenship', Citizenship Studies, vol. 7, no. 2, pp. 139--160

--- 2003b 'Towards a political theory of migrant transnationalism', International Migration Review, vol. 37, no. 3, p. 700-23

BAUBÖCK, RAINER, ERSBÖLL, EVA, GROENENDIJK, KEES \& WALDRAUCH, HARALD 2006 'Acquisition and Loss of Nationality, volume 1: Comparative Analysis'. Amsterdam: Amsterdam University Press

BENHABIB, SEYLA 2007 'Twilight of sovereignty or the emergence of cosmopolitan norms? Rethinking citizenship in volatile times', Citizenship Studies, vol. 11, no. 1, pp. 19--36

BLOMRAAD, IRENE, KORTEWEG, ANNA \& YURDAKUL, GÖKÇE 2008 'Citizenship and immigration: multiculturalism, assimilation and challenges to the nation-state', Annual Review of Sociology, vol. 34, pp. 134--179

BRUQUETAS-CALLEJO, MARIA, GARCÉS-MASCAREÑAS, BLANCA, MORENALEGRET, RICARD, PENNINX, RINUS \& RUIZ-VIEYTEZ, EDUARDO 2008 'Immigration and integration policymaking in Spain', IMISCOE Working Paper, no. 21

CAGLAR, AYSE 2005 'Hometown associations, the rescaling of state spatiality and migrant grassroot transnationalism', Global Networks, A Journal of Transnational Relations, vol. 6, no. 1, pp. 1--22

CASTIÑEIRA, ÀNGEL 2007 'Immigració en estats plurinacionals: el cas de Catalunya', in ZAPATA-BARRERO, R. (ed) Immigració I Autogovern. Barcelona: Proa,

DALMASES, FRANCESC BADIA I 2009 Los gobiernos locales en la acción exterior. Barcelona: CIDOB edicions

DE HAAS, HEIN 2006 'Engaging diasporas. How governments and development agencies can support diaspora involvement in the development of origin countries'. Oxford: International Migration Institute, University of Oxford

FAIST, THOMAS 2007 'Introduction: the shifting boundaries of the political', in FAIST, T. \& KIVISTO, P. (eds) Dual Citizenship in Global Perspective. From Unitary to Multiple Citizenship Basingstoke: Palgrave Macmillan, pp. 1--23

FAVELL, ADRIAN 2001 'Integration policy and integration research in Europe: a review and critique', in ALEINIKOFF, A. D. \& KLUSMEIER, D. (eds) Citizenship Today: Global Perspectives and Practices. Washington: Brookings Institute/Carnegie Endowment for International Peace, pp. 349--99

FONS CATALÁ DE COOPERACIÓ AL DESENVOLUPAMENT 2007a 3r estudi de la cooperació local a Catalunya amb els països de Sud, 2003-2004-2005 Barcelona: Fons Catalá

--- 2007b Linies de Treball 2007. Barcelona: Fons Catalá

--- 2008 Dossier de projectes 2008. Barcelona: Fons Catalá

FOX, JONATHAN 2005 'Unpacking "transnational citizenship"', Annual Review of Political Science, vol. 8, pp. 171--201

GARCÍA, MARISOL 2006 'Citizenship practices and the urban governance in European cities', Urban Studies, vol. 43, no. 4, pp. 745--765

GENERALITAT DE CATALUNYA 2001 'Pla Interdepartamental d'Immigració'. Barcelona: Secretaria per a la Immigració 
---2003 'Plan Director de Cooperación al Desarrollo 2003-2006'. Barcelona: Agencia Catalan de cooperación al desarrollo

--- 2006 'Pla de Ciutadania i Immigració 2005-2008'. Barcelona: Secretaria per a la Immigració

--- 2008 'Pacte nacional de Migració 2005-2008'. Barcelona: Secretaria per a la Immigració

GIL, CARLOS GÓMEZ 2005 'Nuevas vías para el codesarrollo en la cooperación descentralizada', Cuadernos Bakeaz. Políticas de Cooperacion, vol. 72, pp. 1-16

--- 2008 'Una visión panorámica de la cooperación descentralizada de las entidades locales', Cuadernos Bakeaz. Políticas de Cooperacion, vol. 89

GIMENEZ, CARLOS, MARTIINEZ, JULIO L. MARTÍNEZ, GARCÍA, MERCEDES FERNÁNDEZ \& MAISONAVE, ALMUDENA CORTÉS 2006 El

Codesarrollo en España: Protagonistas, Discursos y Experiencias. Madrid: Catarata

GLICK-SCHILLER, NINA \& CAGLAR, AYSE 2008 'Migrant incorporation and city scale: towards a theory of locality in migration studies', Willy Brandt Series of Working Papers. Malmo: Malmo University

GOLDRING, LUIN 2002 'The Mexican state and transmigrant organizations: negotiating the boundaries of membership and participation', Latin American Research Review, vol. 37, no. 3, pp. 55--99

GROENENDIJK, KEES 2008 'Local Voting Rights for Non-nationals in Europe: What We know and What We Need to Learn'. Washington D.C.: Migration Policy Institute

INE 2008 'Avance del Padrón Municipal a 1 de Enero de 2008. Datos Provisionales'. Madrid: Instituto Nacional de Estadistica

IRELAND, PATRICK 2004 Becoming Europe: Immigration, Integration and the Welfare State. Pittsburg: University of Pittsburgh Press

JOPPKE, CHRISTIAN 2008 'Comparative citizenship: a restrictive turn in Europe?' Journal of Law and Ethics of Human Rights, vol. 2, pp. 1-41

KOOPMANS, RUUD \& STATHAM, PAUL 2003 'How national citizenship shapes transnationalism: migrant and minority claims-making in Germany, Great Britain and the Netherlands', in JOPPKE, C. \& MORAWSKA, E. (eds) Toward Assimilation and Citizenship: Immigrants in Liberal Nation-states. Basinstoke: Palgrave MacMillan, pp. 195--238

LACOMBA, JOAN 2004 Migraciones y Desarrollo en Marruecos. Madrid: Catarata LACROIX, THOMAS 2005 Les Réseaux Marocains du Développement. Géographie du Transnational et Politiques du Territorial. Presses de la Fondation Nationale des Sciences Politiques

LEVITT, PEGGY \& DEHESA, RAFAEL DE LA 2003 'Transnational migration and the redefinition of the state: variations and explanations', Ethnic and Racial Studies, vol. 26, no. 4, pp. 587-611

MARÍN, RUTH RUBIO 2006 'Spain', in BAUBÖCK, R., et al. (eds) Acquisition and Loss of Nationality. Amsterdam: Amsterdam University Press, pp. 477--515

MARTINIELLO, MARCO AND LAFLEUR, JEAN-MICHEL 2008 'Towards a transatlantic dialogue in the study of immigrant political transnationalism', Ethnic and Racial Studies, vol. 31, no. 4, pp. $645-663$

MINISTERIO DE ASUNTOS EXTERIORES Y DE COOPERACIÓN 2005 ' Plan Director de la Cooperación española 2005-2008', Madrid 
MINISTERIO DEL INTERIOR 2000 'Programa global de regulación y coordinación de la extranjería y la inmigración, Madrid: Delegacion del gobierno para la extranjería y la inmigracion.

MINISTERIO DE TRABAJO Y INMIGRACIÓN 2007 'Plan Estrategico de Ciudadania e Integración 2007-10', Madrid http://www.mtas.es/es/migraciones/Integracion/PlanEstrategico/Docs/PECIDEF 180407.pdf, accessed 15/5 2007

ØSTERGAARD-NIELSEN, EVA 2001 'Transnational political practices and the receiving state: Turks and Kurds in Germany and the Netherlands', Global Networks: A Journal of Transnational Affairs, vol. 1, no. 3, pp. 261-282

--- 2003a 'International Migration and Sending Countries: Perceptions, Policies and Transnational Relations'. Basingstoke: Palgrave MacMillan

--- 2003b 'The politics of migrants' transnational practices', International Migration Review, vol. 37, no. 3, pp. 665-690

--- 2008 'Dual citizenship: policy trends and political participation in the European Union', Policy Paper. Brussels: European Parliaments' Committee on Constitutional Affairs

--- 2009 'Mobilizing the Moroccans: policies and perceptions of transnational civic engagement among Moroccan migrants in Catalonia', Journal of Ethnic and Migration Studies, vol. 35, no. 10, pp. 1623 - 1641

PAJARES, MIGUEL 2006 'Las políticas locales en ámbito de la inmigración', in ARANGO, E. A. A. J. (ed) Veinte Años de Inmigración en España: Perspectiva Jurídica y Sociológica (1985-2004). Barcelona: Fundación CIDOB, p. 369393

PENNINX, RINUS \& MARTINELLO, MARCO 2006 'Procesos de integración y políticas (locales): estado de la cuestión y algunas enseñanzas', Revista Española de Investigaciones Sociológicas, vol. 116, pp. 123--156

PERO, DAVIDE 2005 'Immigrants and the politics of governance in Barcelona', Compas Working Paper No. 19. Oxford: COMPAS

ROYO, ENRIC 2008 'Co-desarrollo, ¿los riesgos de una tendencia', Opinion. Barcelona: Cidob http://www.cidob.org/es/publicaciones/opinion/desarrollo/codesarrollo los ries gos de una tendencia, 25 January

SASSEN, SASKIA 2002 'Towards post-national and denationalized citizenship', in TURNER, E. F. I. A. B. S. (ed) Handbook of Citizenship. London: Sage, pp. 277--291

SMITH, MICHAEL PETER 2007 'The two faces of transnational citizenship', Ethnic and Racial Studies, vol. 30, no. 6, pp. 1096--1116

SMITH, ROBERT C. 2006 Mexican New York: Transnational Lives of New Immigrants. Berkeley: University of California Press

SOW, PAPA 2005 Migracions Senegaleses a Catalunya: Diagnostic, Maneres de Relacionar-se i de Comunicar-se i Solidaritat amb les Comunitats d'Origen. Barcelona: Fons Català de coooperació al Desenvolupament

SOYSAL, YASEMIN 1994 Limits of Citizenship: Migrants and Postnational Membership in Europe. Chicago: The University of Chicago Press

ZAPATA-BARRERO, RICARD forthcoming 'Dynamics of Diversity in Spain: Old Questions, New Challenges', in VERTOVEC, S. \& WESSENDORT, S. (eds) The Multiculturalism Backlash. European Discourses, Policies and Practices. London: Routledge 
EVA ØSTERGAARD-NIELSEN is Ramon y Cajal research fellow in the Department of Political Science and Public Law, Atonomous University of Barcelona, Bellaterra, 08193 Spain. Email: eva.ostergaard@uab.cat

\footnotetext{
${ }^{1}$ This research has been funded by the Ramon y Cajal Programme of the Spanish Ministry of Science and Innovation.

${ }^{2}$ With regard to of the municipalities, an overview of codevelopment project based on data from migrant associations, NGOs, and the Fons Català database was conducted. 12 municipalities engaged in codevelopment were contacted and further documentary material collected. In-depth interviews were conducted with representatives from 6 municipalities: Sant Celoni, Mataró, Sant Feliu, Barcelona, Montcada I Reixac, and Perpetua de Montgoda. In addition, speeches by representatives of municipal administration at seminars on codevelopment have been recorded and transcribed.

${ }^{3}$ For an interesting analysis of the local to local context for Turkish migrants' transnational engagement, see (Caglar, 2005).

${ }^{4}$ Although the use of term citizenship for this type of activity is an exercise in conceptual overstretching in the view of several scholars (Goldring, 2002; Fox, 2005), who prefer to use the term 'membership' instead.

${ }^{5}$ Please note that the Spanish term ciudadania means both citizenship and membership. Original titles of all policy plans mentioned in the text can be found in the corresponding references.

${ }^{6}$ Nevertheless, a series of reciprocal bilateral agreements have secured local voting rights for migrants from especially Latin American countries.

${ }^{7}$ In particular the European Council Presidency Conclusions on a global approach to migration, December 2005, the EU Commission Communication on migration and development of September 2005 and the position and communication of the Council and Commission respectively 2006 related to the United Nations High Level Dialogue.

${ }^{8}$ Conceptually the work of Sami Naïr for the Interministerial Mission for Development and International Migration (MICOMI) is noted for the innovative idea of making migrants protagonists of migration and actors of development. However, the implementation of the programmes focused on return of migrants and illustrates how codevelopment is embedded in policies to alleviate 'pressure of migration' (Lacroix,
} 2005). 


\footnotetext{
${ }^{9}$ For an overview of codevelopment policies and practices in other parts of Spain see Gimenez et al., (2006).

${ }^{10}$ In more recent Catalan policy documents, such as Catalan Plan of Citizenship and Immigration or or the Annual Plan for Development 2008 by the Catalan Agency for Development Cooperation (ACCD) this conceptualization is not taken much further as it awaits the adoption of a Green Paper on Codevelopment launched in 2008.

${ }^{11}$ This is according to a survey published by Fons Català where they have obtained information about 540 municipalities, of which 140 are not engaged in development work or emergency relief (ibid).

${ }^{12}$ In addition to the projects listed in the Fons Català database there are projects funded by the Catalan Agency for Development Cooperation (ACCD) and other levels of government such as the Barcelona City Council.

${ }^{13}$ See, project 1360 in the database of Fons Catala projects, http://www.fonscatala.org/versio2004/catala/inicio/lineasdetreball/
} 